FIU Law Review

Spring 2014

\title{
Buying West Florida from the Indians: the Forbes Purchase and Mitchel v. United States (1835)
}

Blake A. Watson

University of Dayton School of Law

Follow this and additional works at: https://ecollections.law.fiu.edu/lawreview

Part of the Other Law Commons

Online ISSN: 2643-7759

\section{Recommended Citation}

Blake A. Watson, Buying West Florida from the Indians: the Forbes Purchase and Mitchel v. United States (1835), 9 FIU L. Rev. 361 (2014).

DOI: https://dx.doi.org/10.25148/lawrev.9.2.13

This Article is brought to you for free and open access by eCollections. It has been accepted for inclusion in FIU Law Review by an authorized editor of eCollections. For more information, please contact lisdavis@fiu.edu. 


\title{
Buying West Florida from the Indians: the Forbes Purchase and Mitchel v. United States (1835)
}

\author{
Blake A. Watson*
}

In 1773 and 1775, a handful of individuals purchased lands, located in present-day Illinois and Indiana, from the Illinois Confederacy and the Piankeshaw Indians. The United States Supreme Court, however, disallowed the private sales in Johnson and Graham's Lessee v. McIntosh (1823). ${ }^{1}$ Chief Justice John Marshall announced in Johnson that the European "discovery" of America automatically divested native Indians of the "power to dispose of the soil at their own will, to whomsoever they pleased." 2 Consequently, the Court denied "the power of Indians to give, and of private individuals to receive, a title which can be sustained in the Courts of this country."3

Approximately thirty years later, two trading houses and an individual acquired lands, located south and west of present-day Tallahassee, Florida, from the Creek and Seminole Indians. After protracted litigation, the "Forbes Purchase" was upheld by the Supreme Court in Mitchel v. United States (1835). ${ }^{4}$ Justice Henry Baldwin stated that "the view taken by this Court in the case of Johnson v. M'Intosh ... has received universal assent," ${ }^{5}$ but nonetheless held that the grants at issue were "competent by law to vest a title." 6

When Mitchel was argued, the Supreme Court was at a crossroads regarding the meaning of the controversial "discovery" doctrine. According to Johnson, Indians after discovery held "occupancy" rights that were subject to the discoverer's right of ownership and right of preemption. ${ }^{7}$ Marshall, however, reshaped his conception of aboriginal title in Worcester

\footnotetext{
* Professor of Law, University of Dayton School of Law; J.D. 1981, Duke University School of Law; B.A. 1978, Vanderbilt University.

121 U.S. 543 (1823).

2 Id. at 574. See generally BLAKE A. WATSON, BUYING AMERICA FROM THE INDIANS: JOHNSON v. MCINTOSH AND THE HISTORY OF NATIVE LAND RIGHTS (2012).

3 Johnson, 21 U.S. at 572.

434 U.S. 711 (1835).

5 Id. at 746.

6 Id. at 738 . See also id. at 761 ("[W]e think the title of the petitioner is valid by all the rules prescribed by the acts of congress, which give us jurisdiction of the case”).

7 Thomas Jefferson, in his role as Secretary of State in the Washington Administration, described the right of preemption in Indian lands as "the sole and exclusive right of purchasing from them whenever they should be willing to sell." Thomas Jefferson, XVII THE WRITINGS OF THOMAS JEFFERSON 328 (Andrew A. Lipscomb \& Albert Ellery Bergh eds., 1904).
} 
v. Georgia (1832), declaring in dicta that discovery "gave the exclusive right to purchase, but did not found that right on a denial of the right of the possessor to sell." ${ }^{8}$ In other words, Marshall attempted to turn away from Johnson and return ownership of native lands to the Indians, albeit still subject to the government's right of preemption. ${ }^{9}$

Baldwin makes no mention of Worcester in Mitchel, but instead cites Johnson with approval. In light of this fact, most Indian law scholars have concluded that Mitchel affirmed the Johnson version of the discovery doctrine. $^{10}$ A few scholars, however, have argued that Mitchel actually rejects the Johnson doctrine and instead endorses the views advanced by Chief Justice Marshall in Worcester. ${ }^{11}$ As it turned out, Johnson $v$. McIntosh is the leading American case defining-and limiting-native land rights. Worcester v. Georgia is a prominent case in federal Indian law, but for other reasons. Mitchel $v$. United States is not a prominent case in federal Indian law, although the decision is an important part of Florida history.

This article takes an in-depth look at Mitchel v. United States. In order to place the Forbes Purchase in historical context, Part I provides an overview of European and American control of Florida. Part II details the events that led to the sale by the Creek and Seminole Indians of nearly a million and a half acres in 1804-1806 and 1810-1811. Part III describes the efforts of the purchasers and subsequent grantees to obtain confirmation of the Forbes Purchase. Part IV details the decisions in the Mitchel litigation. The purchase is compared in Part V to other transfers of Indian lands to private individuals, including the sales by the Illinois and Piankeshaw Indians of their homelands in 1773 and 1775. What distinguishes Mitchel from Johnson is the fact that the Spanish government both approved and confirmed the Forbes Purchase. Finally, I explain in Part VI why I disagree with scholars who argue that Mitchel rejects the Johnson doctrine. Rather than embrace Marshall's views of the discovery doctrine set forth in Worcester, the Supreme Court in Mitchel endorsed and applied the Johnson discovery rule.

\section{A BRIEF OVERVIEW OF FLORIDA HISTORY: 1513-1845}

When Spanish explorer Juan Ponce de León came ashore in 1513, there were an estimated 350,000 indigenous inhabitants in Florida,

\footnotetext{
31 U.S. 515, 544 (1832).

See WATSON, supra note 2, at 322-28.

See infra Part VI.

Id.
} 
including the Apalachee, Calusa, Tequesta, and Timucua Indians. ${ }^{12}$ Over time, Spain established settlements at Pensacola and St. Augustine, and asserted authority over the peninsula. However, after being defeated in the Seven Years' War, Spain was forced in February of 1763 to cede East and West Florida to Great Britain. ${ }^{13}$ Eight months later, King George III issued the Royal Proclamation of October 7, 1763, which barred the purchase of native lands "without our especial leave and licence for that purpose first obtained." "14 Great Britain's possession of Florida, however, lasted just two decades. In 1783, following the American Revolution, Spain regained sovereignty over the colony by virtue of the second Treaty of Paris. ${ }^{15}$

The Spanish in 1784 closed New Orleans to American commerce, but the United States was able to secure navigation rights on the Mississippi River in Pinckney's Treaty (the Treaty of San Lorenzo). ${ }^{16}$ The 1795 Treaty also defined the boundaries of East and West Florida; however, the border issue resurfaced in the first decade of the nineteenth century when the United States aggressively asserted that part of West Florida was included in the 1803 Louisiana Purchase. ${ }^{17}$ Thereafter, the Spanish hold on the Florida panhandle grew increasingly tenuous, and in 1818 General Andrew Jackson crossed the border, captured Pensacola, attacked native settlements, and ultimately executed two British subjects suspected of aiding the Seminole and Creek Indians. ${ }^{18}$ In the same year, the Spanish minister, Luis de Onis, and Secretary of State John Quincy Adams, began negotiating the transfer of Florida. The Adams-Onis Treaty was signed on February 22,

12 Glenn Boggs, Florida Land Titles and British, Not Just Spanish, Orgins, 81 FLA. B.J. 7, 23 (July/Aug. 2007); Glenn Boggs, Free Florida Land: Homesteading for Good Title, 83 FLA. B.J. 1, 11 (Jan. 2009).

13 The North American component of the Seven Years' War is known as the French and Indian War. The cession of Florida is set forth in the Treaty of Paris, signed on February 10, 1763. See generally COLIN GORDON CALLOWAY, THE SCRATCH OF A PEN: 1763 AND THE TRANSFORMATION OF NORTH AMERICA (2006). The boundary dividing East and West Florida was the Apalachicola River, located between present-day Tallahassee and Panama City. See Mitchel v. United States, 34 U.S. 711, 738 (1835).

14 American Colonial Documents to 1776, at 642 (Merrill Jensen ed., 1962).

15 Mitchel, 34 U.S. at 720-21; LAWRENCE KinNAird, The SignifiCANCE OF WiLliam Augustus Bowles’ Seizure of Panton’s Apalachee Store IN 1792, at 156 (Univ. Ga. Press, 1931).

16 David E. Wilkins, Johnson v. M'Intosh Revisited: Through the Eyes of Mitchel v. United States, 19 AM. INDIAN L. REV. 159, 171-72 (1994).

17 William S. COKER \& THOMAS D. WATSON, INDIAN TRADERS OF THE SOUTHEASTERN SPANISH BORDERLANDS: PANTON, LESLIE \& COMPANY AND JOHN FORBES \& COMPANY, 1783-1847, 263 (1986); see also Walter W. MANLey II, E. CANTER Brown JR. \& Eric W. Rise, The Supreme COURT OF FlORIDA AND ITS PREDECESSOR COURTS, 1821-1917, at 3 (1997) ("By the 1810s many individuals residing to the north had begun to view the [Florida] colony as ripe for plucking ....”); SidNey WAlter Martin, Florida DURING THE TERritorial DAYs 1-2 (1944) ("The occupation of most of West Florida was a flagrant aggression on Spanish territory, but the Madison administration insisted that it had actually been acquired by the purchase of Louisiana in 1803.”).

18 MARTIN, supra note 17, at 2. Jackson's expedition is known as the First Seminole War. 
1819, but not finally proclaimed until February 22, $1821 .{ }^{19}$ On March 30, 1822, Congress passed "[a]n Act for the Establishment of a Territorial Government in Florida, ${ }^{20}$ authorizing a governor, a legislative council, and two superior courts. After two decades of territorial government, and following the conclusion of the Second Seminole War (1835-1842), Florida became the twenty-seventh state on March 3, 1845.

\section{THE FORBES PURCHASE (1804-1806 AND 1810-1811)}

The story of the Forbes Purchase begins with Panton, Leslie and Company, a trading house formed by five Scottish merchants who remained loyal to Great Britain during the American Revolution. ${ }^{21}$ The merchants, who "had long been established at St. Augustine," persuaded the Spanish monarch, Charles III, to grant them a license "to carry on and continue their commercial operations in [the Florida] provinces and Louisiana." ${ }^{22}$ The Company established trading posts at several locations, including Pensacola and St. Marks, near present-day Tallahassee. ${ }^{23}$ The partners extended credit to their native customers, and the large debt owed by the Seminoles and the Creek Nation was one reason why they agreed to sell tribal lands in 1804 and 1810.

The other reason for the Forbes Purchase was the request for indemnification by Panton, Leslie and Company in response to robberies of the St. Marks store in 1792 and 1800. On January 16, 1792, a party of Indians, led by William Augustus Bowles, plundered the post as part of a British-backed plan to break up the Company's trading monopoly in the region. $^{24}$ On February 21, 1799, the Governor at New Orleans, Manuel

19 MANLEY, BROWN \& Rise, supra note 17 , at 4.

20 Act of Mar. 30, 1822, ch. 13, 3 Stat. 654-659 (1822). The two courts were placed in St. Augustine and Pensacola. In 1824 a third superior court was located at Tallahassee and designated the Middle District. Act of May 26, 1824, ch. 163, 4 Stat. 45-47 (1824).

21 Joseph M. White, Argument in Defence of Indian Sales: Exposition, Historical and Legal, of the Title of Colin Mitchell and Others to Lands in Florida, in A NEW COLLECTION OF LAWS, CHARTERS AND LOCAL ORDINANCES OF THE GOVERNMENTS OF GREAT BRITAIN, FRANCE AND SPAIN, RELATING TO THE CONCESSIONS OF LAND IN THEIR RESPECTIVE COLONIES 711-12 (1839). The original partners were William Panton, John Leslie, Thomas Forbes, Charles McLatchy, and William Alexander. CoKER \& WATSON, supra note 17, at 15. Alexander McGillivray, John Forbes, John Forrester, Robert Leslie, William Simpson, James Innerarity, and John Innerarity also became partners in Panton, Leslie and Company, or its successor, John Forbes and Company. Id. at 363-64.

22 Mitchel v. United States, 34 U.S. 711, 726 (1835). The partners agreed to swear an oath of allegiance to Spain. Id.

23 The site chosen for the St. Marks store was on the west side of the Wakulla River, about four miles above its confluence with the St. Marks River. Mark F. Boyd, Events at Prospect Bluff on the Apalachicola River, 1808-1818, in 16 FLA. HIST. Q. 55, 56-57 (1937) (includes map).

24 With regard to estimates of the value of the merchandise taken, see 4 AMERICAN STATE PAPERS: PUBLIC LANDS 161 (2,674 pounds, 1 shilling); COKER \& WATSON, supra note 17, at 151 (at least \$10,000); id. at 154 (in excess of \$15,000). According to William Panton, the robbery was 
Gayoso de Lemnos, informed William Panton that Spain had no objection to the trading company's plan to obtain a cession of Indian lands in the United States as payment for debts owed and losses due to theft. ${ }^{25}$ Following a second robbery of the St. Marks store in May of 1800, the representatives of Panton, Leslie and Company petitioned the King of Spain directly for indemnification. ${ }^{26}$

William Panton died on February 26, 1801, and the name of the trading house was later changed to John Forbes and Company. ${ }^{27}$ The remaining partners continued to seek reimbursement, but now sought a cession of Indian lands within Spanish Florida. In January of 1804, James Innerarity informed the governor of West Florida, Vincente Folch, of "offers made at a general meeting of the Indians in the month of June last, by various chiefs of the Seminole tribe, to ... cede... a portion of the lands occupied by the said Indians....,28 Governor Folch granted

committed by "a party of freebooting Indians, at whose head was the notorious William Augustus Bowles, and a number of the chiefs of the villages of Cowetas, Broken Arrow, Hitchetas, Ufales, Chichas, and inhabitants of the point named Ousutches...." 4 AMERICAN STATE PAPERS: PUBLIC LANDS 161 (statement of William Panton to Don Vincente Folch y Juan, Governor of West Florida, at Pensacola, on Jun. 2, 1799); see also James F. Doster, THE CreEK InDians AND THEIR FloRidA LANDS, 1740-1823, at 245 (1974).William Bowles, who was born in Maryland in 1763, was a Loyalist with two wives, a Cherokee and a daughter of a Creek chief. After the 1792 robbery of the St. Marks trading post, Bowles was captured by the Spanish and sent to the Philippines. During a return trip to Spain, he escaped and eventually returned to Florida. He declared himself the Director General of the Muskogee Nation. In May of 1800, he once again plundered the store at St. Marks. At an Indian council on May 24, 1803, Bowles was seized by his opponents and turned over to the Spanish authorities. He died in a Havana prison in 1805. See generally J. LEITCH WRIGHT, JR., WiLLiaM Augustus Bowles: Director General of THE Creek Nation (1967). Bowles was backed by Lord Dunmore, the Governor of the Bahamas who sided with Loyalist refugees opposed to Panton, Leslie and Company. Kinnaird, supra note 15, at 158, 165-72; see also COKER \& WATSON, supra note 17, at 115, 151. Dunmore, when he was the royal governor of Virginia prior to the American Revolution, was one of the twenty individuals who purchased two large tracts of land in October 1775 from the Piankeshaw Indians; see WATSON, supra note 2, at 77-99.

25 Mitchel, 34 U.S. at 727; DOSTER, supra note 24, at 245.

26 John Forbes and John Innerarity, in an affidavit dated August 25, 1802, stated that the May 1800 robbery was carried out by "a party of freebooting Indians, at whose head was the notorious William Augustus Bowles, and a number of the chiefs of the Oakfuskies, Otassies, Cowetas, Casitas [Cussetas], Chickas, Tallasses, Eanckeeches, and Mickasukies.” DosTER, supra note 24, at 246. These Indians represented towns of the Upper Creeks, Lower Creeks, and the Seminoles. Id. In support of their request for indemnification, the partners of Panton, Leslie and Company stressed the "great importance and services of the house as a political instrument of the government; that they had a right to indemnity from the king; that the situation of the house was such, that they must sink under their losses if it was not afforded; and that it must be sustained and preserved as indispensable to retain any control over the Indians, and secure the possession of the provinces entrusted to their care.” Wilkins, supra note 16, at 172-73; Mitchel, 34 U.S. at 726-27.

27 COKER \&WATSON, supra note 17, at 235, 250.

285 American State Papers: Public Lands 331 (James Innerarity, Pensacola, to Governor General Folch, Jan. 5, 1804). After describing the preliminary negotiations with the Indians, Innerarity requested "permission to establish a talk upon this business with the Indians, and, upon a cession being effected, that there may be confirmed and secured to the house the possession of the lands ceded ...." 
permission to proceed with the cession, subject only to the condition that "the lands which the petitioner shall obtain from the Indians shall not be disposed of without the knowledge and consent of this government." 29

The deed of cession, signed by twenty-four Lower Creek and Seminole chiefs on May 25, 1804, stated that:

[W]e, the undersigned chiefs of the Seminole tribe assembled together, having maturely weighed the enormous debts which we owe to the house of Panton, Leslie \& Co.,... [] and being likewise responsible for the robberies and depredations which, on two occasions, we have perpetrated on the stores of the aforesaid house... we have determined . . . to sell and to cede ... a district of land which we hold as actual owners and proprietors[]. ${ }^{30}$

The transaction was confirmed on June 22, 1804, by Governor Folch at Pensacola. $^{31}$ The Upper Creeks objected, however, and consequently a second deed (with a few modifications) was signed by chiefs from the Upper Creeks, Lower Creeks, and Seminoles on August 22, 1804, at Prospect Bluff (Chackeoheithlee) on the Apalachicola River. ${ }^{32}$ The cession consisted of approximately one million acres. ${ }^{33}$ The Indian grantors confirmed the August 1804 cession four months later, in front of Governor Folch at Pensacola. ${ }^{34}$ The Upper Creeks, however, renewed their opposition to the cession in 1806, necessitating the execution of a third deed at the Spanish fort at St. Marks. ${ }^{35}$ Governor Folch confirmed the transaction on December 3, 1806, once again with the condition that the lands not be sold without the approval of the Spanish government. ${ }^{36}$

The acquisition of lands by Panton, Leslie and Company in 1804-1806 was almost immediately followed by an application from its successor, John Forbes and Company, for permission to negotiate a similar cession as

Id. Yahulla Emathly, one of the Seminole chiefs, had met in 1803 with John Forbes at Pensacola, where they reached a general agreement on a tract of land to be ceded to the company. After other chiefs were informed of these negotiations, James Innerarity petitioned Governor Folch to permit the cession and to confirm it upon completion. COKER \& WATSON, supra note 17, at 247.

295 AMERICAN STATE PAPERS: PUBLIC LANDS (decree by Governor Folch, dated Jan. 7, 1804); see also Mitchel, 34 U.S. at 727.

305 American StATE PAPERS: Public LANDS 332 (deed of cession dated May 25, 1804). The transaction took place at Cheskatalafa, an Indian village located on the west side of the Chattahoochee River in present-day Henry County, Alabama. Boyd, supra note 23, at 62.

315 AMERICAN STATE PAPERS: PUBLIC LANDS 332 (1860).

32 Id. at 332-33; DOSTER, supra note 24, at 249-51, 256-57.

33 COKER \& WATSON, supra note 17 , at 251-54.

345 American StATE PAPERs: Public LANDS 333 (decree by Governor Folch, dated Dec. 5, 1804); see also DOSTER, supra note 24, at 257; COKER \& WATSON, supra note 17, at 254.

355 American State PAPERs: Public LANDs 333-34 (deed of cession, dated Aug. 2, 1806, at St. Marks of Apalachie).

36 Id. at 334 (decree of confirmation by Governor Folch, dated Dec. 3, 1806). 
compensation for additional debts owed by the Creek and Seminole Indians. ${ }^{37}$ The second series of transactions started in April of 1810 with a deed transferring tracts of land that were contiguous to the prior grant. In addition to the cession of land in favor of John Forbes and Company, the Lower Creek and Seminole ceded to John Forbes personally an island in the Apalachicola River as compensation for services rendered since $1785 .^{38}$ Governor Folch gave his approval on June 15, 1810, with the same condition that the lands could not be sold or otherwise transferred without the approval of the Spanish government. Seven months later, on January 22, 1811, the principal chiefs of the Creeks and Seminoles confirmed the 1810 cession with another deed signed at Pensacola in the presence of Folch. $^{39}$ On April 22, 1811, and May 25, 1811, additional deeds were signed confirming the grants to both John Forbes and Company and to John Forbes in his individual capacity. ${ }^{40}$ On June 15, 1811, the cessions were again ratified by Governor Folch. ${ }^{41}$

The entire "Forbes Purchase" totaled approximately 1.4 million acres located between the Apalachicola and Wakulla rivers. ${ }^{42}$ According to one source, the lands "comprised all of the present counties of Franklin and Liberty, as well as a large part of [the counties of] Gadsden, Leon and Wakulla." ${ }^{43}$ In October of 1817 John Forbes obtained permission to sell most of the company lands acquired from the Indians to Colin Mitchel, a Havana merchant who claimed American, English, and Spanish

37 See Mitchel v. United States, 34 U.S. 711, 727 (1835) (“Another application was made to the same governor in 1807, for his permission to make an additional purchase from the same Indians.”); John C. Upchurch, Aspects of the Development and Exploration of the Forbes Purchase, 48 FLA. HIST. Q. 117, 119 (1969) ("To the newly reorganized firm went all the rights and privileges of the former company, as well as all property.”).

385 AmERicAn StATE PAPERs: PUBliC LANDS 333-34 (description of deed of cession, agreed to at Cuskataloofa, on the Chatahoochie River, in April 1810); see also COKER \& WATSON, supra note 17, at 268; DOSTER, supra note 24, at 260-61 (describing the cession of lands on Apr. 19, 1810).

395 AMERICAN STATE PAPERS: PUBLIC LANDS 335; see also Doster, supra note 24, at 262; COKER \& WATSON, supra note 17, at 269-70; see also id. at 253 (map of the "Forbes I" grant [the 18041806 and 1810-1811 Indian cessions] and the "Forbes II" grant [a tract of land given by Spain for losses incurred during the War of 1812; not at issue in Mitchel v. United States]).

404 AmERICAN STATE PAPERS: PUBLIC LANDS 165-66 (summarizing the Apr. 22, 1811, and May 25, 1811, deeds).

41 DOSTER, supra note 24, at 262.

42 COKER \& WATSON, supra note 17 , at 328.

43 Boyd, supra note 23, at 63. Another source describes the Forbes Purchase as an area one-third larger than the State of Rhode Island consisting of lands in Gulf and Calhoun counties, as well as Franklin, Liberty, Gadsden, Leon, and Wakulla counties. A.J. Hanna, Diplomatic Missions of the United States to Cuba to Secure the Spanish Archives of Florida, in HISPANIC AMERICAN ESSAYS 21718 (1942); see also WILLIAM WARREN ROGERS, OUTPOSTS ON THE GULF: SAINT GEORGE ISLAND AND APALACHICOLA FROM EARLY EXPLORATION TO WORLD WAR II 46 (1986) (map describing Forbes Purchase as including the southwestern part of Leon County, the southern portion of Gadsden County, all of Franklin County and Wakulla County, and all but the northern tip of Liberty County). 
citizenship. $^{44}$

It was by no means clear, however, that Mitchel would be able to profit from his land speculation. The geopolitical landscape had undergone a dramatic transformation since the Forbes Purchase was completed. The attack on Fort Mims by the "Red Sticks" from the Upper Creek towns in August of 1813 was followed by a crushing defeat at the hands of Andrew Jackson at Horseshoe Bend in March of $1814 .^{45}$ Spanish influence also weakened during the first two decades of the nineteenth century, leading to the cession of Florida in the 1821 Adams-Onis Treaty. The Forbes claimants were no doubt alarmed when Adams proposed the annulment of all grants of land in Florida made after August 11, 1802, but the two countries eventually agreed to a different date in Article 8 of the Treaty:

All the grants of land made before the 24th of January 1818 by His Catholic Majesty or by his lawful authorities in the said Territories ceded by His Majesty to the United States shall be ratified and confirmed to the persons in possession of the lands, to the same extent that the same grants would be valid if the territories had remained under the dominion of His Catholic Majesty. ${ }^{46}$

Over the next fourteen years, Colin Mitchel and his associates would argue that the Forbes Purchase was a valid grant, that must be upheld by the United States, pursuant to Article 8 of the Adams-Onis Treaty. The validity of the purchase was first questioned by a board of land commissioners, and then rejected by a territorial court in Florida. Ultimately, however, the Forbes Purchase was upheld by the United States Supreme Court in Mitchel

445 American STATE PAPERs: Public LANDS 335-36 (petition of John Forbes, dated Oct. 9, 1817, to the governor of Cuba, Jose Cienfuegos; decree of Governor Cienfuegos, dated Oct. 13, 1817, permitting "the alienation of the lands solicited by John Forbes \& Co.”). Prior to granting approval, Cienfuegos sought the opinion of the Assessor General, who concluded that "there is no obstacle to your excellency's making use of the powers intrusted to you, and permitting the alienations proposed ....” Id. at 336. Forbes did not sell the island that had been conveyed to him in his individual capacity. Colin Mitchel acted on behalf of Carnochan and Mitchel, a Georgia-based trading firm, and purchased the lands in 1819 for himself, his brothers, Robert, Peter, and Octavius, John Richard, and William Carnochan. Upchurch, supra note 37, at 122; see also Hanna, supra note 43, at 219 (Mitchel "could claim British protection by virtue of his birth in Scotland, was entitled to the privileges of a citizen of the United States by naturalization, [and] his residence of twenty-five years in Cuba and marriage to a Spanish woman, together with letters patent, constituted him a subject of Spain ....”).

45 MANLEY, BROWN \& Rise, supra note 17, at 5. Fort Mims was located north of Mobile, Alabama. The Battle of Horseshoe Bend took place in present day Tallapoosa County in east-central Alabama.

46 Boggs, Florida Land Titles and British, Not Just Spanish, Origins, supra note 12, at 10 (emphasis added); see also WHITE, supra note 21, at 701; COKER \& WATSON, supra note 17 , at 327. The United States insisted on Article 8 because large portions of Florida had been granted by the King of Spain to his friends prior to the proclamation of the Treaty. The compromise date, January 24, 1818, invalidated the Alagaon, Punonrostro, and Vagas grants, the three largest royal land grants. MARTIN, supra note 17 , at 6 . 
v. United States.

\section{EFFORTS TO OBTAIN CONFIRMATION OF THE FORBES PURCHASE}

The validity of the Spanish land grants was a pressing concern in Florida, and Congress quickly responded with legislation authorizing the creation of a Board of Commissioners for both East Florida and West Florida. ${ }^{47}$ With respect to claims in excess of one thousand acres, the land commissioners were directed to "report the testimony, with their opinions, to the Secretary of the Treasury, to be laid before Congress for their determination." 48 On November 12, 1824, the Board of Commissioners for West Florida submitted its report to Treasury Secretary William Crawford. ${ }^{49}$ With respect to the Forbes Purchase, the commissioners focused their inquiry on two issues: whether the Indians were "competent to make a conveyance to lands, to be held and possessed 'in full right and entire property;"” and whether Governor Folch was "vested with the power to make a grant, or confirm one of this description."50 With respect to the first issue, the commissioners reached the following conclusion:

[T] he Indians could make no conveyance vesting fee simple. Were the contrary admitted, the confirmation of Governor Folch would have been superfluous.... [T] he Indians collectively have no fee simple right to lands within the Floridas ... [but] seem to have enjoyed only a usufructuary right, in which they were protected as long as they continued in possession of the land. ${ }^{51}$

Although the language employed is consistent with the reasoning of Chief Justice John Marshall in Johnson v. McIntosh, the commissioners did not mention the Supreme Court decision, which had been handed down on February 28, 1823. ${ }^{52}$

47 An Act for Ascertaining Claims and Titles to Land Within the Territories of Florida, ch. 129, 3 Stat. 709 (1822).

48 Id. at 718

494 AMERICAN STATE PAPERs: PUBLIC LANDS 156 (Feb. 22, 1825).

50 Id. at 169.

51 Id. With regard to the power of Governor Folch to make such a grant, the commissioners stated that "we are not apprised of any law or ordinance by which it was warranted." Id. The commissioners also reported on the grant to John Forbes in his individual capacity, referring Congress to the reasoning set forth in their opinion on the validity of the cession to John Forbes and Company. Id. at 204-05. John Forbes had died on May 13, 1823. COKER \& WATSON, supra note 17, at 329. Octavius Mitchel, who presented the Forbes Purchase claim to the board of commissioners on behalf of Colin Mitchel and the other proprietors, was a member of the Florida territorial legislative council in 1823. MARTIN, supra note 17 , at 36.

52 See Johnson v. McIntosh, 21 U.S. 543, 591 (1823) (“[T]he Indian inhabitants are to be considered merely as occupants, to be protected, indeed, while in peace, in the possession of their lands, but to be deemed incapable of transferring the absolute title to others.”). The reasoning of the commissioners is also consistent with statements made by Marshall in Fletcher v. Peck, 10 U.S. 87, 142- 
Congress did not act on the commissioners' recommendation regarding the Forbes Purchase. ${ }^{53}$ Meanwhile, to further bolster his claim, Colin Mitchel asked the Governor of Cuba, Francisco Dionisio Vives, to permit Vincente Folch to explain his position regarding "the right of property of the Indians to the lands in Florida" and the power of the Spanish authorities "to approve and confirm their properties." 54 In September of 1827, Folch reaffirmed the validity of the Forbes Purchase:

$[\mathrm{N}] \mathrm{o}$ question or doubt was ever raised ... a to the right and power of the Indians to pay their debts with that part of land which belonged to them in absolute property.... [T]he Government has always acknowledged the right of property and sovereignty of the Indians to their lands, with right to alienate, cede, and give, without having, at any time, been understood as confined only to the use ... .55

Four months later, on January 3, 1828, the Senate received a memorial from Robert Mitchel "and others" seeking approval of the Forbes Purchase. ${ }^{56}$ The memorialists argued that the right of the Indians to sell the lands was based on "their aboriginal tenure of possession, and by the confirmation of that tenure by the formal acts of the Spanish and British governments, who alternatively claimed dominion over them., 57

Congress took no action on the memorial, but instead enacted legislation on May 23, 1828, authorizing Florida land claims in excess of 3,500 acres to be adjudicated in the territorial courts, with the right of appeal to the Supreme Court. ${ }^{58}$ Consequently, on October 18, 1828, a petition to confirm the Forbes Purchase was filed in Tallahassee with the Superior Court for the Middle District of Florida. ${ }^{59}$ The petition, to which

43 (1810) (observing that "a state can be seised in fee of lands, subject to the Indian title," and noting that "the nature of the Indian title, which is certainly to be respected by all courts, until it be legitimately extinguished, is not such as to be absolutely repugnant to seisin in fee on the part of the state ....”).

53 The reports of the two Florida land boards were submitted to the House of Representatives in February of 1825. 4 AMERICAN STATE PAPERS: Public LANDS 155-56 (Feb. 22, 1825). Congress, by legislation enacted on April 22, 1826 and February 7, 1827, did take action on most of the other Spanish land grants addressed by the commissioners. Hanna, supra note 43, at 213.

54 Colin Mitchell, Record in the Case of Colin Mitchell and Others, versus The United StATES: SupReme COURT OF THE United STATES, JANUARY TERM, 1831, at 230 (1831) (letter, dated Aug. 19, 1827, from Colin Mitchel to Governor Vives) [hereinafter “1831 RECORD”], available at http://books.google.com/books?output=text\&id=xWdGAAAAYAAJ\&dq=record+colin+mitchell\&jtp=2 30. Folch was also asked to comment on his jurisdiction over the lands at issue. Id.

55 Id. at 231-35 (letter, dated Sept. 22, 1827, from Folch to Vives).

565 AMERICAN State PAPERS: Public LANDS 329 (memorial, dated Dec. 31, 1827).

57 Id. at 330; see also id. at 331 ("[T]he parties were competent, and the government consummated it with a 'complete ultimate' title.").

58 Act of May 23, 1828, ch. 70, 4 Stat. 284, 284-86 (1828).

59 The petition was filed by:

Colin Mitchell, Robert Mitchell, in his own right, and as assignee of the estate and effects of the 
was appended numerous exhibits, asserts " $[\mathrm{t}] \mathrm{hat}$ the Indians had the right to convey the said lands, for that they were the original possessors, and possession was guarantied to them by the treaty of 1784, and other treaties."60

The petitioners had attempted to engage Florida's first delegate to Congress, Richard Keith Call, but he requested a fee that was deemed exorbitant. ${ }^{61}$ The claimants instead obtained the services of the current delegate, Joseph M. White, despite the fact that he was one of the land commissioners who in 1824 had recommended against confirmation of the Forbes Purchase. ${ }^{62}$ During his tenure as land commissioner, White had exposed a scheme by Call and other prominent individuals to defraud the government. $^{63}$ The two men became bitter rivals, and Call challenged White to a duel during the election of 1825 (in which White defeated Call's candidate). ${ }^{64}$

In addition to White, the petitioners employed John Berrien, David Bayard Ogden, and Daniel Webster. Berrien was the current Senator for the state of Georgia and Ogden was an eminent New York attorney who often appeared before the Supreme Court. ${ }^{65}$ The celebrated Webster-who previously represented the claimants in Johnson v. McIntosh-had recently

mercantile house heretofore trading under the firm of Carnochan and Mitchell, and as trustee for the creditors of said firm, and also of Richard Carnochan, William Calder, Benjamin Marshall, Benjamin W. Rogers, John P. Williamson, the heirs and legal representatives of John McNish, deceased, and James Innerarity.

1831 RECORD, supra note 54, at 3.

601831 RECORD, supra note 54, at 13. In Article 13 of the 1784 treaty, Spain promised the Indians "the security and guarantee of those [lands] which they hold, according to the right of property with which they possessed them, on condition that they are comprehended within the lines and limits of his Catholic Majesty.” 5 AMERICAN STATE PAPERS: PUBLIC LANDS 336 (extract from the treaty of Jun. 1, 1784, made at Pensacola, between Spain and the Talpuche and Seminole Indians).

61 Herbert J. Doherty, JR., Richard Keith CALl: SOUthern Unionist 69 (1961). Call served as territorial delegate from 1823 to 1825.

624 American STATE PAPERS: PuBliC LANDs 169 (Feb. 22, 1825). White’s actions were not unprecedented: Robert Goodloe Harper argued that Indian title was a "mere privilege" in Fletcher v. Peck, 10 U.S. 87, 123 (1810), but contended in Johnson v. McIntosh, 21 U.S. 543, 562 (1823), that the Piankeshaw Indians were the owners of the lands in dispute and had the power to convey a complete title to private individuals.

63 MARTin, supra note 17, at 73; ERNEST F. DiBBLE, JOSEPH MiLLS WHITE: ANTI-JACKSONIAN FLORIDIAN 22-23 (2003).

64 Edward E. BAPtist, CREATING AN Old SOUTH: MidDle FlORIDA’s Plantation Frontier BEFORE THE CIVIL WAR 88-89 (2002); Jackson Wilder Maynard, Jr., “According to Their Capacities and Talents”: Frontier Attorneys in Tallahassee During the Territorial Period (Mar. 30, 2004) (unpublished M.A. thesis, Florida State University), available at http://diginole.lib.fsu.edu/etd/2639.

65 See Robert TAYlor Swaine, The Cravath FIRM AND ITS PREDECESSORS, 1819-1947, at 27 (1946). In January of 1828, Berrien unsuccessfully sponsored a bill in the Senate that would have made it easier to prove Florida land claims based on Spanish grants. Royce Coggins McCrary, Jr., John MacPherson Berrien of Georgia (1781-1856): A Political Biography (1971) (unpublished Ph.D. thesis, University of Georgia). 
moved from the House of Representatives to the United States Senate. The petition in the Florida Superior Court was filed by White and Berrien, who appear to have been the primary advocates for the Mitchel claimants.

The appointment of counsel for the United States was complicated by the transition to the Jackson administration on March 4, 1829. During the final months of the Adams presidency, Attorney General William Wirt stressed the need to employ capable counsel to litigate the complex and immense Spanish land grants. Wirt recommended Joseph White, only to learn that he had been retained by the Mitchel and Arredondo claimants. ${ }^{66}$ Adams nevertheless employed White to defend the United States in certain cases, including claims founded on British grants. ${ }^{67}$

When Jackson became President, he selected John Berrien to be Attorney General. Berrien, however, was allowed to continue to represent the claimants in the Mitchel and Arredondo cases, despite Richard Call's protestations to Jackson that such engagements were "incompatible with his duties as attorney-general of the United States." "68 William Wirt was engaged to replace Berrien in the Mitchel and Arredondo cases, and Call was selected by Jackson to serve (as "assistant counsel") with James Ringgold, the District Attorney of Middle Florida, and Richard C. Allen, the territorial "law agent." 69

The judge for the Superior Court of the Middle District of the Territory of Florida was Thomas Randall, who had moved to Florida shortly after marrying the daughter of William Wirt. ${ }^{70}$ Randall was from Maryland, where he had studied law under Thomas Johnson, the shareholder in the Illinois and Wabash Land Company, who gave his name to the Johnson $v$. McIntosh litigation. ${ }^{71}$ President James Monroe sent Randall to Cuba in 1824 in an unsuccessful attempt to retrieve documents relating to the

66 MANLEy, BROWn \& RISE, supra note 17, at 50. The Arredondo claim involved 289,645 acres in northeastern Florida. United States v. Arredondo, 31 U.S. 691, 691 (1832).

67 DOHERTY, supra note 61, at 58 ("So it was that ... the assistant counsel for the United States was appearing against the United States in the two cases involving the largest Florida land grants ....”); McCrary, supra note 65, at 171 ("Berrien's role in the Florida cases ... seem[s] a bit peculiar, even for his times.”).

68 DOHERTY, supra note 61, at 55 (letter, dated Mar. 28, 1829, from Call to Jackson); see also McCrary, supra note 65, at 153-55 (describing Berrien's arrangement with Jackson). McCrary notes that Berrien was kept informed of the federal government's litigation strategy in the Florida cases, "which must have made it easier for [him] to represent the opposing side." Id. at 170, n.88.

69 See 1831 RECORD, supra note 54, at 644-45; DOHERTY, supra note 61, at 57, 72; Maynard, supra note 64, at 40, 78. The Act of May 23, 1828, authorizing the superior court to adjudicate large Spanish land grants, also authorized the appointment of an "assistant counsel" and a "law agent" to defend the interests of the United States. Act of May 23, 1828, ch. 71, 4 Stat. 286. Despite his title, Call took a lead role in the litigation, appearing in both the Superior Court and Supreme Court.

70 MANLEY, BROWN \& RISE, supra note 17, at 42-43.

71 Id. at 54. 
Spanish land grants in Florida. ${ }^{72}$ In 1827 , Wirt purchased a plantation near Tallahassee and arranged for his son-in-law to be appointed by President Adams as the local territorial judge. ${ }^{73}$ According to one source, Judge Randall soon thereafter "was identified with [Richard] Call's political associates and aspirations ....,74

To recap, during the Mitchel litigation the claimants suing the United States were represented by a former federal land commissioner (White), who was currently employed by the United States in other land grant disputes, and the United States Attorney General (Berrien), who otherwise supervised litigation for the federal government. The attorneys for the United States included Richard Call, the Tallahassee Land Office Receiver who had previously challenged White to a duel, ${ }^{75}$ and William Wirt, the father-in-law of Judge Thomas Randall. ${ }^{76}$ In addition to being married to the daughter of one of the lawyers representing the United States, Judge Randall was a friend of Call and had previously traveled to Cuba-on behalf of the government - to retrieve documents relevant to the validity of

72 Hanna, supra note 43, at 211. President Monroe had previously designated Randall in 1823 as a special minister of the United States in order to travel to Puerto Rico and the West Indies and investigate piracy in the area. MANLEY, BROWN \& RISE, supra note 17, at 54.

73 DOHERTY, supra note 61, at 85; MANLEY, BROWN \& RISE, supra note 17, at 54-55. Randall was reappointed by President Jackson in 1831 and in 1836. Hanna, supra note 43, at 212 n.12.

74 MANLEY, BROWN \& RISE, supra note 17, at 56.

75 A close friend of Andrew Jackson, Call served as territorial delegate from 1823 to 1824, and then secured for himself the lucrative position of Receiver of Public Monies in the General Land Office in Tallahassee. DoherTy, supra note 61, at 40. If the Forbes Purchase had been invalidated, Call would have personally profited for two reasons: as Land Office Receiver he earned commissions from the sale of federal lands, and as a speculator he would have been able to purchase lands within the Forbes Purchase at the government price of $\$ 1.25$ per acre. Id. at 69. Call became one of the most wealthy and powerful men in middle Florida, and served two terms (1836-1839 and 1841-1844) as Florida's territorial governor. See Maynard, supra note 64, at 15, 35, 38, 61; BAPTIST, supra note 64, at 91 (Call used his position at the Land Office "to divert land and profits to a clique of allies and relatives”). He was, however, less successful as an advocate before the Supreme Court: he lost all fifteen cases he argued. DoHERTY, supra note 61, at 69.

76 William Wirt's position on Indian land rights is difficult to pin down. In 1819 he declared in a letter that Indians "have no more right to sell the standing timber ... than they have to sell the soil itself.” Robert W. McCluggage, The Senate and Indian Land Titles, 1800-1825, 1 W. HIST. Q. 415, 471 (1970). As Attorney General, he stated that "[t]he conquerors have never claimed more than the exclusive right of purchase from the Indians .... They do not hold under the States, nor under the United States; their title is original, sovereign, and exclusive." 1 OfFicial OPINIONS OF THE AtTORNEYs GENERAL 466-67 (Apr. 26, 1821). As counsel for the Cherokee Nation, he prepared the complaint filed in the Supreme Court which asserted the principle that "the first European discoverer has the prior and exclusive right to purchase these lands from the Indian proprietors ... [is] a principle to which the Indian proprietors have never given their assent, and which they deny to be a principle of the natural law of nations, or as in any manner obligatory on them.” RICHARD PETERS, THE CASE OF THE CHEROKEE NATION AgAinst THE StATE OF GEORGia 4 (1831) (complaint filed by the Cherokee Nation in Cherokee Nation v. Georgia, 30 U.S. 1 (1831)); see also WATSON, supra note 2, at 323-24 (Wirt's complaint, filed on behalf of the Cherokee Nation, "denied that Indian nations are no longer free to sell their lands to whomsoever they please"). 
the Forbes Purchase! ${ }^{77}$

The government, in its answer to the petition, asserted that:

[T] he Indians had a mere possessory interest in the lands they occupied, a mere privilege of hunting, raising stock, \&c., and that they never have been considered as the absolute 'fee simple' proprietors of the soil, with the power of selling and disposing of the ultimate dominion and property, since the occupation and settlement of their country by European nations. ${ }^{78}$

Although the answer does not mention either Johnson v. McIntosh or the doctrine of discovery, the government did declare that its view of native land rights conformed to "a principle of the law of nations, applicable to the Indian tribes of Louisiana and Florida, and of North America generally.",79

Proceedings were held in abeyance in order for Richard Call to travel to Cuba in another attempt to procure documents relating to the Forbes claim and other land grants. ${ }^{80}$ During this time period Congress engaged in a heated debate over the Indian Removal Act. Senator John McKinley, of Alabama, asserted that "the case of Johnson and McIntosh" held that "the natives had no title to the soil," Georgia described as "a fundamental principle" the notion that "Indians had no right either to the soil or sovereignty of the countries they occupied ...." 82 The Indian Removal Act, which was signed into law by President Jackson on May 28, 1830, led directly to the infamous Trail of Tears. By one estimate, one quarter to one half of the Cherokee, Creek, and Seminole population died as a consequence of removal. ${ }^{83}$

77 Randall and Call (who went to Cuba in 1830 on a similar mission) believed the petitioners in Mitchel, as well as other claimants relying on Spanish land grants in Florida, were fraudulently altering documents to bolster their cases. See generally Hanna, supra note 43.

781831 RECORD, supra note 54, at 653-54 (answer of the United States, dated Jun. 20, 1829).

79 Id. at 654.

80 See Hanna, supra note 43, at 209-14; DOHERTY, supra note 61, at 59 ("[D]espite the refusal of the authorities in Cuba to deliver the records, the claimants of Florida lands continued to produce originals or authenticated copies of documents purporting to establish their claims. This caused many persons, Call among them, to believe that Spanish officials were in collusion with the holders of questionable land claims in Florida.”).

81 The Indians, VI Reg. Deb. 45, 353 (1830) (Apr. 17, 1830) (speech by Senator Peleg Sprague of Maine, describing prior remarks by Senator John McKinley of Alabama).

82 Removal of Indians, 1830 GALE \& SEATON'S REg. at 1024 (May 17, 1830). On the other hand, Senator Theodore Frelinghuysen of New Jersey claimed that "we have distinctly recognized their title; treated them as owners, and in all our acquisitions of territory, applied ourselves to these ancient proprietors, by purchase and cession alone, to obtain the right of soil.” The Indians, 1830 GALE \& SEATON’s REG. at 312 (Apr. 9, 1830); see also WATSON, supra note 2, at 319-22.

83 Russell Thornton, Cherokee Losses During the Trail of Tears: A New Perspective and a New Estimate, 31 EтHNOHISTORY 289, 289 (1984). The Choctaw and Chickasaw, who traveled shorter distances, also suffered terrible losses. Id. 


\section{THE DECISIONS IN THE MITCHEL LITIGATION}

The hearing in Mitchel $v$. United States commenced in Tallahassee in July of $1830 .{ }^{84}$ On November 2, 1830, Judge Thomas Randall dismissed the petition, holding the deeds to be null and void "because the Indians had not, by virtue of any title recognised to belong to them by Spain, such an interest or estate in the lands as enabled them to sell and convey it away to these petitioners in full property...." 85 In support of his conclusion, Randall relied heavily on Johnson v. McIntosh:

In adjudicating, now, upon titles derived from Indian grants, the courts of the United States are no longer left to grope their way in obscurity and uncertainty over an unexplored field. The decision of the Supreme Court in the case of Johnson and McIntosh ... has so clearly settled the principles applicable to the subject... as to leave but little occasion for hesitation or doubt in future cases. ${ }^{86}$

After quoting extensively from the Johnson decision, Randall held that Spain, Great Britain, and the United States all denied "any right on the part of the Indians, by the proper vigor of their own original title of occupancy, to convey away the ultimate dominion or property of the soil to any third party." ${ }^{\text {,7 }}$ He further held that the Spanish government, by treaty or otherwise, never recognized any right of the Florida Indians to sell and convey a complete title to their lands. ${ }^{88}$

An appeal bond was filed in November and the cause was docketed in the Supreme Court on February 2, $1831 .{ }^{89}$ Arguments in the case did not begin, however, until February 10, $1835 .^{90}$ The primary reason for the delay was the continued efforts of the United States to obtain documents from the Spanish government in order to prove that Mitchel and other claimants had bribed authorities to forge and alter records. ${ }^{91}$ During the

84 See 1831 RECORD, supra note 54, at 644. Prior to 1838, the territorial court "seems to have held its session wherever a suitable room could be found; from time to time it ordered the payment of rent for a courtroom to the City Council of Tallahassee, Jackson Masonic Lodge, and the trustees of Leon Academy.” Maynard, supra note 64, at 36. Joseph White argued on behalf of the petitioners, and Richard Call, James Ringgold, and Richard Allen represented the United States. Id. at 40; DIBBLE, supra note 63 , at 128 .

851831 RECORD, supra note 54, at 645. The opinion takes up ninety pages of the record. Id. at 644-734.

86 Id. at $669-70$.

87 See id. at 675.

88 Id. at 676. Randall acknowledged that Governor Folch stated otherwise in 1827, but held that his position "has never been acknowledged by any European nation." Id. at 695.

89 Id. at 734; see also DOHERTY, supra note 61, at 64.

9012 John Marshall, The Papers of John Marshall 561 (Charles F. Hobson ed., 2006) (indicating that Mitchel was argued on February 10-11, 23-28, and March 2-4, 1835).

91 See Hanna, supra note 43, at 220-21. Fraud was in fact exposed in connection with a large 
intervening time period, the Supreme Court decided four cases that were relevant to Mitchel $v$. United States.

The first two cases concerned Indian rights. In 1831, in Cherokee Nation v. Georgia, John Marshall held that the Indian tribes are "domestic dependent nations" and hence not "foreign states" entitled to invoke the original jurisdiction of the Court. ${ }^{92}$ Justice Baldwin, who had been appointed in 1830 by President Jackson, declared that Indian tribes were neither sovereign nations nor foreign states. ${ }^{93}$ With respect to native land rights, Baldwin stated that Johnson v. McIntosh "is too explicit to be misunderstood," and clearly established that "from the time of discovery" the Indians held occupancy rights only, and that "the ultimate absolute fee, jurisdiction and sovereignty was in the government." "T4 The following year the Supreme Court decided Worcester v. Georgia, and held that a state statute regulating activities within the limits of the Cherokee Nation was unconstitutional. $^{95}$ As previously noted, ${ }^{96}$ John Marshall retreated in Worcester from his "discovery gave title" statement in Johnson, ${ }^{97}$ and stated in dicta that discovery conferred only "the exclusive right of purchasing such lands as the natives were willing to sell." in Worcester, but did not deliver an opinion for publication. ${ }^{99}$

The other two cases relevant to Mitchel involved the validity of Spanish land grants in Florida. In United States v. Arredondo, the Federal Government challenged the genuineness of the document introduced as evidence of the grant, which supposedly conveyed 289,645 acres in northeastern Florida in 1817 to Fernando de la Maza Arredondo and his son. ${ }^{100}$ Justice Baldwin authored an opinion in favor of the claimants which

grant of land, estimated at about 1,500,000 acres, which had been granted to John Forbes and Company for services rendered to the Spanish government and losses sustained by the company. DoHERTY, supra note 61, at 62. The date of this grant-which was not at issue in the Mitchel litigation-had obviously been altered in an effort to avoid the annulment in the 1821 Treaty of all grants by Spain made after January 24, 1818. Id.

92 Cherokee Nation v. Georgia, 30 U.S. 1, 17 (1831).

93 Id. at 31-50; see WATSON, supra note 2, at 323-25.

94 Cherokee Nation, 30 U.S. at 32-33.

9531 U.S. 515, 561 (1832) ("The Cherokee nation . . . is a distinct community occupying its own territory, with boundaries accurately described, in which the laws of Georgia can have no force.”).

96 See supra notes 8-9 and accompanying text.

97 Johnson v. McIntosh, 21 U.S. 543, 573 (1823).

98 Worcester, 31 U.S. at 545; see also id. at 544 ("[T]he nation making the discovery ... [obtained] the sole right of acquiring the soil ....”).

99 Id. at 596; see also Lyndsay G. Robertson, Justice Henry Baldwin's “Lost Opinion” in Worcester v. Georgia, 24 J. SuP. CT. HIST. 50, 54 (1999) ("Baldwin based his dissent on his conclusion that the Court lacked jurisdiction, as the record had been returned by the Georgia court clerk, and not by the court itself.”).

100 United States v. Arredondo, 31 U.S. 691, 716 (1832). The Arredondo claimants were represented by Joseph White, John Berrien, and Daniel Webster. The United States was represented by 
rejected the fraud claim, relying in part on the principle that "a public grant is to be taken as evidence that it issued by lawful authority ...."101 The land grant at issue in United States v. Clarke was also upheld, with Chief Justice John Marshall noting that "[a] grant made by a governor, if authorized to grant lands in his province, is prima facie evidence that his power is not exceeded." 102 According to historian Charles Warren, in these two cases the Supreme Court:

[E]stablished the public land policy of the Government on the basis of the most scrupulous respect for treaties, preferring to preserve the honor, rather than the property of the government, and to run the risk of confirming possibly fraudulent claims rather than to impair the reputation of the Government with foreign nations. ${ }^{103}$

The outcome in Mitchel was no doubt influenced by the Court's respect for treaty rights and obligations as expressed in Arredondo and Clarke. The petitioners' main arguments before the Supreme Court in Mitchel were that: (1) "[t]he Indian sales of 1804 and 1811, and the several acts in confirmation thereof by the governor of West Florida, vest in the grantees a full and complete title to the land in controversy;” and (2) these actions "amount to an acquiescence on the part of the king of Spain and his legitimate authorities; which, according to the laws and usages of that kingdom, would vest a valid title in the grantees." 104 The United States, in

Richard Call, William Wirt, and Roger Taney, who had replaced Berrien as Attorney General in July of 1831.

101 Id. at 729. The United States also argued that the lands could not be granted by Spain because they were Indian lands. The Court, however, accepted the determination of Spanish authorities that the lands had been abandoned. See id. at 747 ("The title of the Indians to these lands is not a matter before us; the grant is made subject to their rights if they return to resume them, and their abandonment has been ascertained by a proceeding which the intendant in the grant calls a sentence pronounced by him in his official character.”).

102 United States v. Clarke, 33 U.S. 436, 451 (1834). After his defeat in Arredondo, but before his defeat in Clarke, Richard Call ran against Joseph White in the 1833 election for territorial delegate. He lost.

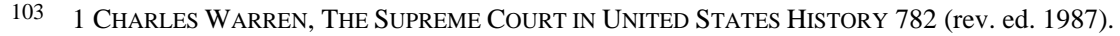

104 Mitchel v. United States, 34 U.S. 711, 718 (1835) (emphasis added). In Mitchel, unlike prior cases, we also have the benefit of a printed brief setting forth the petitioners' arguments. See WhiTE, supra note 21. In their brief, the petitioners argue that (1) the Forbes Purchase was not subject to the British Royal Proclamation of 1763; (2) the Royal Proclamation was deemed necessary because, without it, Indians held the power to convey "a full and complete title" to their lands to private individuals; and (3) therefore, the Creek and Seminole Indians had the power to transfer a complete title to the Forbes grantees. Id. at 714-15. A similar negative inference argument, however, was rejected in Johnson $v$. McIntosh, 21 U.S. 543, 604 (1823) ("The acts of the several colonial assemblies, prohibiting purchases from the Indians, have also been relied on, as proving, that, independent of such prohibitions, Indian deeds would be valid. But, we think ... the fact that such acts have been generally passed, is strong evidence of the general opinion, that such purchases are opposed by the soundest principles of wisdom and national policy.”). According to his biographer, it was Joseph White who "carried the argument" for the petitioners. DIBBLE, supra note 63, at 129. 
response, contended that the Indian deeds "did not, either in themselves, or with the confirmation thereof by governor Folch, convey to the grantees therein named, any legal right to the lands in question."105 With regard to the latter point, the government argued that, for various reasons, Governor Folch had no power to ratify and confirm the Indian cessions. ${ }^{106}$

It did not bode well for the United States that Justice Henry Baldwinthe author of Arredondo-wrote the opinion in Mitchel v. United States instead of Chief Justice John Marshall, who had spoken for the Court in all prior decisions involving Indian land rights, including Johnson $v$. McIntosh. ${ }^{107}$ The issue in Mitchel, as framed by Baldwin, was whether the claimants to the Forbes purchase had acquired-either by (1) the law of nations, (2) the stipulations of any treaty, (3) the laws, usages, and customs of Spain, or the province in which the land is situated, or (4) the acts of Congress or proceedings under them-"a right which would have been valid if the territory had remained under the dominion and in possession of Spain."108 Just as in the Arredondo and Clarke cases, the Supreme Court accepted the genuineness of the deeds and documents, ${ }^{109}$ and presumed that actions taken by Spanish authorities were authorized and lawful. ${ }^{110}$

Baldwin then examined "the nature and extent of the Indian title to these lands." 111 In this part of his opinion, Baldwin notes that "the view taken by this court of Indian rights in the case of Johnson v. M'Intosh ... has received universal assent," 112 and restates the Johnson conception of native property rights as follows: "Indians were protected in the possession of the lands they occupied, and were considered as owning them by a perpetual right of possession in the tribe or nation inhabiting them, [but] ...

105 Mitchel, 34 U.S. at 720 (emphasis added). The United States also argued that the facts of Mitchel were distinguishable from the facts in Arredondo and Clarke: "The claim ... does not profess to be founded on any original substantive grant made by the king of Spain or his officers; but on cessions made by Indian tribes, and on alleged ratifications and confirmations thereof, and acquiescence therein, by the Spanish authorities.” Id. By the time of the oral argument, William Wirt had died and Benjamin Butler had replaced Roger Taney as Attorney General.

106 Id. at 721-22.

107 Mitchel was handed down on the last day of the term, March 17, 1835, and was the last case in John Marshall's long and illustrious career. The seventy-nine year old jurist died on July 6, 1835. LeONARD BAKer, John MARShall: A LifE in LAW 766 (1974); JEAN EdWARD SMith, JoHN MARSHALL: DEFINER OF A NATION 522 (1996).

108 Mitchel, 34 U.S. at 734.

109 Id. at 730.

110 Id. at 735 (“[T]he eighth article [of the 1821 Adams-Onis Treaty] expressly recognizes the existence of these lawful authorities in the ceded territories, designating the governor or intendent, as the case might be, as invested with such authority, which is to be deemed competent till the contrary is made to appear"); id. at 741 ("[W]e cannot feel authorized to declare that governor Folch usurped any powers vested in the intendant, in any of his acts relating to these lands.”).

111 Id. at 745.

112 See id. at 746. 
the ultimate fee was in the crown and its grantees ...."113 With regard to the right of private individuals to purchase lands, Baldwin was careful to distinguish private purchases without government approval (such as the transactions at issue in Johnson) and private purchases with government sanction (such as the Forbes Purchase):

Individuals could not purchase Indian lands without permission or license from the crown, colonial governors, or according to the rules prescribed by colonial laws; but such purchases were valid with such license, or in conformity with the local laws; and by this union of the perpetual right of occupancy with the ultimate fee, which passed from the crown by the license, the title of the purchaser became complete. ${ }^{114}$

Relying once more on Johnson v. McIntosh as binding authority, Baldwin states that "all title held under . . . license of the crown to purchase from the Indians have been held good, and such power has never been denied ...."115 Because the Forbes Purchase was licensed and confirmed by Spanish authorities; and because "the law presumes the existence in the provinces of an officer authorized to ... give license to purchase and to confirm," 116 the Court was "unanimously of opinion, that the title of the petitioner ... is valid by the law of nations; the treaty between the United States and Spain...; the laws and ordinances of Spain, under whose government the title originated; the proceedings under said treaty, and the acts of congress relating thereto.”"117

\section{OTHER SALES OF INDIAN LANDS TO PRIVATE INDIVIDUALS}

What distinguishes Mitchel v. United States from Johnson v. McIntosh is the fact that the Spanish government both approved and confirmed the Forbes Purchase, whereas the British Government, the State of Virginia, the Continental Congress, and the United States Congress refused to sanction either the 1773 purchase from the Illinois Confederacy or the 1775 purchase from the Piankeshaw Indians. Although there were a few instances of unconfirmed private purchases of Indian lands in colonial America, such

113 Id. at 745.

114 Id. at 746 (emphasis added).

115 Id. at 747 (citing Johnson v. McIntosh, 21 U.S. 543, 595-604 (1823)).

116 Mitchel, 34 U.S. at 760; see also ERNEST SUTHERLAND BATES, THE STORY OF THE SuPREME COURT 135 (1982) (The Mitchel Court "refused to go behind a formal grant to consider evidence of fraud behind it.”); DOHERTY, supra note 61, at 67 ("The Indian grants were upheld as ... having been made according to Spanish law and practice, and the copies of the confirmation documents were accepted despite Call's protestations.”).

117 Mitchel, 34 U.S. at 761. In addition to upholding the validity of the Forbes Purchase, the Court also confirmed the title to the island in the Apalachicola River granted to John Forbes in his personal capacity, even though the claim was pending before the Superior Court in Florida. Id.; see also DOHERTY, supra note 61, at 68. 
[Vol. 9:361

transactions were rare and considered aberrations. ${ }^{118}$ In BUYING AMERICA FROM THE INDIANS, ${ }^{119}$ I examine, in detail, the unsuccessful efforts of the Illinois and Wabash Land Companies, and other land speculators to convince government officials that Indian tribes own the lands they occupy, and can convey a valid and complete title to private individuals. For purposes of this article, it suffices to briefly discuss the most prominent examples of purchases of Indian lands without government approval or confirmation.

The Puritan Roger Williams was banished from the Massachusetts Bay Colony because of his belief that Europeans could "justly occupy lands in the Americas only by purchasing those lands from their rightful owners, the Indians." ${ }^{120}$ In 1638, Williams obtained the right to settle in present-day Rhode Island by virtue of a deed from the local Indians. ${ }^{121}$ Williams, however, deemed it necessary to go to England to obtain a charter for "Providence Plantations," which was either an independent grant of royal land or, at minimum, a confirmation by the Crown of his prior purchase. ${ }^{122}$

In 1667 Puritans from Connecticut relocated and founded Newark, New Jersey, by purchasing a 20,000-acre tract in exchange for goods in kind, including "four barrells of beere." ${ }^{23}$ Eight years later, a panel of prominent English lawyers rendered their legal opinion that the private purchase of Indian land was invalid because "the Prince[, ...] who make the Discovery[,] hath the Right of the Soyle \& Govermt of that place." The opponents of the Newark purchase went so far as to assert that claiming title to land "by an Indian Deed only" was tantamount to "High Treason" insofar as it suggested "the Indian Grantor to be the Superior Lord of that Land ....”125 A lawsuit was filed in the eighteenth century, but the case

118 See WATSON, supra note 2, at 22. John Marshall, in Johnson v. McIntosh, acknowledges "that many tracts are now held in the United States under the Indian title, the validity of which is not questioned," but characterizes such transactions as aberrations, and notes that "there is no case, so far as we are informed, of a judicial decision in their favour.” 21 U.S. 543, 600-01 (1823).

119 See WATSON, supra note 2.

120 WiLliam CHRISTIE MACLEOD, THE AMERICAN INDIAN FrONTIER 199 (1928).

121 WATSON, supra note 2, at 14.

122 Id.; see also Johnson, 21 U.S. at 603 (determining that the royal charter for Rhode Island "can amount to no acknowledgment, that the Indian grant could convey a title paramount to that of the crown, or could, in itself, constitute a complete title. On the contrary, the charter of the crown was considered as indispensable to its completion”).

123 JOHN T. CUNNINGHAM, NEWARK 24 (1966).

12413 Documents Relative to the Colonial History OF THE State OF NEW YoRK 486-87 (E.B. O’Callaghan ed., 1881).

1256 ARChives of the State of NeW JERSEy, 1St SERIES, DOCUMENTS Relating to THE COlOnial, ReVOlutionary AND POST-REVOlutionARY History OF THE STATE OF NEW JERSEY 31922 (William A. Whitehead et. al. eds., 1738-1747). 
was never concluded and the Indian deed was never upheld. ${ }^{126}$

George Croghan, a trader who was once described as the "foremost living expert on the western Indian country,"127 purchased from the Iroquois Indians several large tracts of land in western Pennsylvania. The Iroquois sold Croghan two hundred thousand acres in 1749, four thousand acres in 1754, one and a half million acres in 1773 , and six million acres in $1775 .{ }^{128}$ Although Croghan did not obtain prior authorization for his purchases, he did acknowledge the Crown's authority, and consequently sought royal confirmation until about 1770 , when he began to contend that the private purchases from the Indians transferred full title. ${ }^{129}$ In 1764 British officials refused to ratify Croghan's private purchases of Iroquois land. ${ }^{130}$ In the early 1770s, when Croghan attempted to sell part of his 1749 grant to George Washington, the future president offered to buy fifteen thousand acres "when a legal title was established." 131 A committee of the Continental Congress in 1781 recommended confirmation of Croghan's acquisitions, but based on the disputed rationale that the purchases had been effected with "consent and approbation" of government officials. ${ }^{132}$ The purchases were never upheld.

In 1767, the Sioux Indians purportedly granted to explorer Jonathan Carver a large tract of land in present-day Minnesota and Wisconsin. ${ }^{133}$ Carver and his heirs initially sought royal ratification of the purchase, but later argued that government approval was not necessary. The Senate Committee on Public Lands concluded on January 23, 1823, that Carver's alleged Indian deed "could not vest the legal title in him." 134 The matter was finally resolved in 1825, when the House Committee on Private Land Claims declared that the invalidity of private purchases was "settled beyond controversy" in "the case of Johnson against McIntosh."135

The private purchase in colonial America that most closely resembles the Forbes Purchase is the "Indiana grant" negotiated between the "suffering traders" and the Iroquois Indians in connection with the 1768 Treaty of Fort Stanwix. In 1754, and again in 1763, Pennsylvania

126 See, e.g., WATSON, supra note 2, at 25.

127 NiCHOLAS B. WAINWRIGHT, GEORGE CROGHAN: WILDERNESS DiPLOMAT 306 (1959).

128 WATSON, supra note 2, at 47, 53, 62.

129 Id. at 47.

130 Id.

131 AlBert T. VOlWILER, GeOrge Croghan AND the WeSTWARD MOVEMENT, 1741-1782, at 292 (1926).

132 WATSON, supra note 2, at 145-46.

133 See id. at 59.

1343 AMERICAN STATE PAPERS: PUBLIC LANDS 534.

1354 AmERicAn StATE PAPERS: Public LANDs 84 (1825); see also WATson, supra note 2, at 275-76. 
merchants suffered losses due to Indian warfare, and George Croghan was appointed by the "suffering traders" to travel to England to obtain restitution in the form of a large tract of land. ${ }^{136}$ When British officials declined to grant land as compensation for the traders' losses, a decision was made to obtain restitution directly from the Iroquois. The merchants and their creditors formed the Indiana Company and distributed gifts in anticipation of the treaty conference at Fort Stanwix in the fall of 1768. Pursuant to a carefully orchestrated plan, the Iroquois first deeded to the Indiana Company an immense tract of land in what is now West Virginia and eastern Kentucky. The Indians and their grantees then attempted to include the terms of the transaction in the treaty with Great Britain, hoping to increase the likelihood of royal sanction. ${ }^{137}$ British officials, however, refused to ratify the Indiana grant, which led to further political maneuvering and a new proposal-by the "Grand Ohio Company"-for approval of a colony that would include and uphold the Indiana grant. In May of 1773, the British Board of Trade signed off on the plan of government for the "Vandalia" colony, but the unfolding events heralding the American Revolution ensured that the project would never proceed. ${ }^{138}$ The Indiana Company shareholders then obtained opinions from respected English and American legal authorities regarding the validity of their grant. ${ }^{139}$ The Indiana grant, however, was never confirmed. ${ }^{140}$

On March 17, 1775, Richard Henderson and the Transylvania

136 WATSON, supra note 2, at 48-53.

137 Id. at 56-58.

138 Id. at $58-61$

139 In March of 1775, Henry Dagge of Lincoln's Inn in London offered his opinion that the recipients of the 1768 grant "hath a good, lawful and sufficient title," and a month later, Serjeant-at-Law John Glynn declared that the Iroquois "had a power of alienating and transferring in any manner, or to any persons, unless they had been restrained by their own laws.” See SAMUEL WHARTON, ViEw OF THE Title to Indiana, A Tract of Country on the River OHio 22-24 (1775). Patrick Henry and Benjamin Franklin, during the Second Continental Congress, informed the Indiana Company that they concurred with the views of Dagge and Glynn. 11 LAWrenCE HENRY GiPSON, THE British EMPIRE Before the American ReVolution: THE TRIumphant EMPIRE, THE Rumbling of the COMing STORM 1766-1770, at 483 n.105 (1965). In his printed brief in Mitchel v. United States, Joseph White refers to the opinions of Dagge, Glynn, Henry, and Franklin. WHITE, supra note 21, at 716-18. Judge Randall and Justice Baldwin make no mention of the opinions, which were also unsuccessfully invoked by the Johnson claimants. See WATSON, supra note 2, at 253.

140 In 1779, the State of Virginia declared the Indiana grant to be null and void and refused to compensate the shareholders. WATSON, supra note 2, at 104-05. As with the case of George Croghan, see supra note 132 and accompanying text, a committee of the Continental Congress in 1781 recommended confirmation of the Indiana grant based on the assumption that the purchase had been approved by Great Britain. No action was taken, however, forcing the Indiana Company to file suit against Virginia in 1792 in federal court. The plaintiffs in Grayson v. Virginia claimed that the 1768 Iroquois grant was valid even without government confirmation. The suit, which was renamed Hollingsworth v. Virginia, was dismissed in 1798 after the passage of the Eleventh Amendment. See id. at 190 . 
Company purchased from the Cherokee Nation a vast region between the Cumberland and Kentucky Rivers. The Company shareholders asserted that the Cherokees had an absolute right to sell their land, but acknowledged that the lands were located within the charter boundaries of Virginia. ${ }^{141}$ Not content with mere jurisdiction, the Virginia General Assembly in June of 1776 declared the purchase to be null and void and then included a clause in the state constitution that "no purchases of lands shall be made of the Indian natives, but on behalf of the public, by authority of the General Assembly." 142 On November 4, 1778, the Virginia House of Delegates again declared the purchase to be invalid, but resolved that it is "just and reasonable" to compensate the shareholders "for their trouble and expense."143

In 1795 and 1796, John Askin, Sr., a British subject living in Detroit, and his associates entered into several purchase agreements with the Ottawa, Chippewa, and Potawatomi Indians for large portions of presentday Michigan and northern Ohio. ${ }^{144}$ In order to profit from their investments, Askin advised his son, John Askin, Jr., to meet with the Indians assembled at the Fort Greenville treaty conference and persuade them to insist that the treaty confirm their right to dispose of their lands "as they think fit without any restraint Whatsoever." "145 The junior Askin, however, was not allowed to participate in the treaty negotiations, and Article V of the Treaty of Greenville instead reaffirmed the government's preemptive right to control the disposition of Indian lands. ${ }^{146}$

141 The 1775 deed stated that the Indian grantors held their title "in fee simple" and were authorized to convey the territory. WATSON, supra note 2, at 88, 103.

142 Id. at 103-04; VII FEDERAL AND STATE CONSTITUTIONS, COLONIAL CHARTERS, AND OTHER

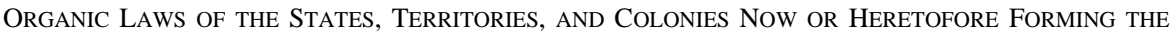
UNITED STATES OF AMERICA 3819 (Francis N. Thorpe ed., 1909).

143 GeORge W. RANCK, BoONESBOROUgh 253 (1971); WATson, supra note 2, at 143. The land granted by Virginia is the present site of Henderson, Kentucky.

144 The lands purchased included a large tract along the Maumee River, including present-day Toledo, Ohio, another tract along the southern shore of Lake Erie, and a third tract comprising most of Michigan’s lower peninsula. WATSON, supra note 2, at 88, 179.

1454 CORRESPONDENCE OF LIEUTENANT-GOVERNOR JOHN GRAVES SimCOE 35 (E. A. Cruikshank ed., 1926) [hereinafter Cruikshank] (letter, dated Jul. 5, 1795, from John Askin, Sr., to John Askin, Jr.).

146 WATSON, supra note 2, at 179-80. In his report to the Secretary of the Army, General "Mad" Anthony Wayne noted that "influential Characters" had counseled the Indians "to insist upon the [a]bsolute \& inherent right of disposing of all their Lands either by sale deed or gift, how [w] hen \& to whomsoever they please, \& to make this right the first Article of the treaty." ANTHONY WAYNE: A NAME in ARMS, SOldier, Diplomat, DEFENDER of EXPANSION WESTWARd of A NATION: THE WAYNE-KNOX-PICKERING-MCHENRY CORRESPONDENCE 461 (Richard C. Knopf ed., 1960). When the terms of the Greenville Treaty were announced, the British commandant at Detroit remarked that Askin and other land speculators "have been severely disappointed by the Treaty, and their purchases of course set aside.” Cruikshank, supra note 145, at 92 (letter, dated Sept. 8, 1795, from Colonel Richard England to Lieutenant-Governor John Graves Simcoe). 
Private purchases of Indian lands were exceedingly rare in the nineteenth century, and claims to Indian lands based on transactions in the prior century were invariably denied. In 1805, the House Committee on Public Lands of Representatives declared that a 1779 grant by the Piankeshaw Indians to George Rogers Clark lacked government approval and was void. ${ }^{147}$ Likewise, in 1819, the Senate Committee on the Public Lands reported against a claim by Loyalist Alexander Macomb to land granted by the Potawatomi Nation. ${ }^{148}$ It is not surprising, therefore, that the transactions at issue in Johnson v. McIntosh were rejected by the Board of Land Commissioners at Vincennes (Indiana) in 1806, and again by the Board of Land Commissioners at Kaskaskia (Illinois) in 1810. ${ }^{149}$ The 1773 and 1775 purchases were made without prior permission of the British Government and thus contravened the 1763 Royal Proclamation. The grantees sought Crown approval, but instead provoked General Major General Frederick Haldimand to issue his own proclamation reiterating that all purchases of Indian lands without royal approval "will be considered as void and fraudulent." 150 Virginia consistently opposed the efforts of speculators to establish marketable title to lands purchased from Indian tribes, and the Continental Congress, the United States Congress, and ultimately the United States Supreme Court refused to confirm the purchases. $^{151}$

1471 American State PAPers: Public LANDS 229 (report, dated Dec. 23, 1805, on Clark’s petition). The claim was denied. 15 AnNALS OF CONG. 301 (1805). The land at issue was located across the Ohio River from present-day Louisville, Kentucky. Virginia in 1784 did award 150,000 acres to Clark and his men in acknowledgement of services rendered during the American Revolution. WATSON, supra note 2, at 108-09.

1483 American State Papers: Public Lands 360 (report, dated Jan. 15, 1819) ("It is ... believed the United States have, in no instance, recognised an Indian grant, whether made under the British or American Government, as valid to give title, such grants being prohibited by the laws and regulations of both."). The Committee reported favorably on a claim to an island that was based on adverse possession. Id.

149 WATSON, supra note 2, at 232-33.

1508 THE PAPERS OF SIR WILLIAM JohNSON 1074-76 (Alexander C. Flick ed., 1933) (proclamation, dated Mar. 10, 1774, of General Frederick Haldimand)

151 Whereas the 1781 committee of the Continental Congress recommended upholding the purchases by George Croghan and the Indiana Company, the same committee recommended that the 1773 and 1775 purchases from the Illinois and Piankeshaw Indians be declared invalid. Among the reasons given for its decision, the committee noted that latter purchases "had been without license of the then government or other public authority ...." 22 JOURNALS OF THE CONTINENTAL CONGRESS 230 (1782); see also WATSON, supra note 2, at 144-47. The Illinois and Wabash Land Companies submitted numerous memorials to Congress seeking confirmation of the grants. The 1810 memorial contained most of the legal arguments that would later be presented to the Supreme Court in Johnson v. McIntosh. Id. at 243-49. The House Committee on Public Lands resolved that the petition "ought not be granted" because the transactions were prohibited by the "plain and express" requirement of government approval in the 1763 Royal Proclamation. 2 AmERICAN StATE PAPERS: Public LANDS 219-20 (report, dated Jan. 30, 1811) 
DOES MITCHEL REJECT THE JOHNSON DISCOVERY DOCTRINE?

I have argued elsewhere that the rights of ownership, possession, and disposition in native lands can be aggregated or diffused, leading to four different conceptions of indigenous land rights:

(1) The indigenous inhabitants own the lands they occupy and also hold the right of possession. In addition, the indigenous inhabitants are free to sell or transfer their property rights to whomsoever they please. Preexisting indigenous property rights were unaffected by European "discovery."

(2) The indigenous inhabitants continue to own the lands they occupy but, after discovery, cannot sell their lands to whomsoever they please. The discoverer holds a "right of preemption," giving the discoverer the exclusive right to acquire the property rights of the indigenous inhabitants.

(3) The indigenous inhabitants continue to possess the lands they occupy but, after discovery, no longer own the lands they occupy. The discoverer owns the land subject to the native title, i.e., the right of possession (or occupancy). The discoverer/owner can transfer ownership notwithstanding the native title. The discoverer/owner has the exclusive (preemptive) right to extinguish the native title. Once the native title is extinguished, the discoverer/owner of the lands also has the right of possession.

(4) The indigenous inhabitants have no property rights. The discoverer owns the land and holds the possessory rights. The indigenous inhabitants are trespassers (or perhaps "tenants at will”). When the discoverer/owner makes payments to the indigenous inhabitants, it does so to expedite their removal, not to acquire property rights. ${ }^{152}$

I have also previously contended that the Johnson conception of native land rights falls within the third category, whereas John Marshall's revised view of native land rights in Worcester falls within the second category. ${ }^{153}$ In this article, I assert that Justice Baldwin and the Supreme Court endorsed and applied the Johnson discovery rule in Mitchel v. United States.

Other scholars have reached the same conclusion. Felix Cohen noted in 1947 that, while Mitchel differs from Johnson insofar as the Forbes

152 Blake A. Watson, The Doctrine of Discovery and the Elusive Definition of Indian Title, 15 LEWIS \& CLARK L. REV. 995, 998-99 (2011) [hereinafter Watson, Discovery Doctrine]; WATSON, supra note 2 , at 274,357 . The view that the indigenous inhabitants have no property rights was the position adopted by Great Britain with respect to the Australian Aborigines.

153 See generally Watson, Discovery Doctrine, supra note 152. While I wholeheartedly support the repudiation of the doctrine of discovery, I believe that the differences between the Johnson and Worcester conceptions of Indian title-which both place limits on native disposition rights - can be overstated. Id. at 1024 n.145. 
Purchase was "made with the consent of the sovereign," the Mitchel Court nonetheless endorsed the Johnson view that Indian title was a "right of possession" and that "the ultimate fee was in the crown and its grantees."154 In his book Common Law Aboriginal Title, Kent McNeil likewise states that the Johnson discovery rule "was again restated" in Mitchel when Justice Baldwin held that Indians held a "right of possession" but not the "ultimate fee," which "was in the crown and its grantees."155 Lindsay Robertson contends that, whereas Marshall changed his views on Indian title in Worcester, Baldwin restored Johnson formulation of the discovery doctrine in Mitchel, ${ }^{156}$ and Matthew Fletcher agrees that "Worcester's rejection of the Johnson rule... was itself rejected in the 1835 Term in Mitchel v. United States."157

John Hurley was the first to argue that the Mitchel decision endorses Marshall's dicta in Worcester. ${ }^{158}$ But the leading proponent of this position is David Wilkins, who has written extensively in the field of federal Indian law. ${ }^{159}$ In his 1994 article on Mitchel v. United States, Wilkins argues that Mitchel is "a stunning ruling" and "an implicit repudiation of the doctrine of discovery" because it "fundamentally contradicts the doctrines enunciated in M'Intosh," by holding that "tribes may alienate their aboriginal territory to whomever they wish...."160 Eight years later, Wilkins, and co-author Tsianina Lomawaima, in their book, UNEVEN GROUND: AMERICAN INDIAN SOVEREIGNTY AND FEDERAL LAW, assert that Mitchel "denied the McIntosh precedent . . . by disavowing that the doctrine

154 Felix S. Cohen, Original Indian Title, 32 MinN. L. REV. 28, 50 (1947).

155 Kent MCNEIL, COMMON LAW ABORIGINAL TitLE 253-54 (1989).

156 Lindsay G. Robertson, Conquest By LAw: How the Discovery of America DisPosSESSED INDIGENOUS PEOPLES OF THEIR LANDS 138-39 (2005).

157 Matthew L.M. Fletcher, The Iron Cold of the Marshall Trilogy, 82 N.D. L. REV. 627, 647 (2006).

158 John Hurley, Aboriginal Rights, the Constitution and the Marshall Court, 17 REVUE JURIDIQUE THÉMIS 403, 440 (1982-83) (Baldwin's views of Indian title “confirmed and developed those advanced by Johnson in Fletcher v. Peck and by Marshall in Worcester v. Georgia"). For the views of Justice William Johnson, see Fletcher v. Peck, 10 U.S. 87, 145-48 (1810); WATSON, supra note 2, at 241-43.

159 See, e.g., DAVID E. Wilkins, AmERICAN Indian SOVEREIGNTY AND the U.S. SupremE Court: THE MASKING OF JUSTICE (1997); VINE DELORIA, JR. \& DAVID E. WiLKINS, TRIBES, TREATIES, AND CONSTITUTIONAL TRIBULATIONS (1999); DAVID E. WILKINS \& TSIANINA LOMAWAimA, UNEVEN GROUND: AMERICAN INDIAN SOVEREIGNTY AND FEDERAL LAW (2002); VinE DELORIA, JR. \& DAVID E. WiLKINS, THE LEGAL UNIVERSE: OBSERVATIONS ON THE FOUNDATIONS OF AMERICAN LAW (2011); DAVid E. WilKins \& HEIDI KiIWETINEPINESIIK STARK, AMERICAN INDIAN POLITICS AND THE AMERICAN POLITICAL SySTEM (3d ed. 2011); DAVID E. WILKINS, THE NAVAJO POLITICAL EXPERIENCE (4th ed. 2013); David E. Wilkins, Hollow Justice: A History of Indigenous Claims in the UNITED STATES (2013).

160 Wilkins, supra note 16, at 175 (“stunning ruling”); supra note 16, at 176 ("implicit repudiation”); supra note 16, at 159-60 (“fundamentally contradicts”); supra note 16, at 160 (“tribes may alienate”). 
of discovery vested absolute ownership of America in the discovering states." 161

I respectfully disagree with the position taken by Hurley, Lomawaima, and Wilkins regarding the meaning of Mitchel v. United States. It is difficult to accept the view that Mitchel "denied the McIntosh precedent" when Justice Henry Baldwin expressly stated in Mitchel that "the view taken by this Court in the case of Johnson v. M'Intosh ... has received universal assent."162 In particular, I believe that two statements in Baldwin's lengthy (and dense) opinion have created confusion. ${ }^{163}$

The first statement is Baldwin's observation that the native right of occupancy "is considered as sacred as the fee simple of the whites."164 Wilkins and other scholars appear to contend that Justice Baldwin equated aboriginal title with the English common law fee simple absolute. ${ }^{165}$ However, in support of his "as sacred as the fee simple" statement, Baldwin cited Cherokee Nation v. Georgia, where John Marshall held that the Indian right of occupancy to their lands is "as sacred as the fee-simple, absolute title of the whites," but then explained that "they are only rights of occupancy, incapable of alienation, or being held by any other than common right without permission from the government." "166 Marshall, in turn, cited to his 1823 Johnson opinion, where he had observed that "[t]he absolute ultimate title has been considered as acquired by discovery, subject only to the Indian title of occupancy, which title the discoverers possessed the exclusive right of acquiring."167 Rather than chart a new path in Mitchel, Baldwin was restating the Johnson discovery rule: that Indian title is not a right of ownership (since discovery divested Indians of ownership of their lands) but rather is a right of occupancy (possession) that is "as sacred as the fee-simple." The Supreme Court in Tee-Hit-Ton Indians $v$. United States (1955) made it clear that Indian title is not the equivalent of

161 WILKINS \& LOMAWAIMA, supra note 159, at 60.

162 Mitchel v. United States, 34 U.S. 711, 746 (1835).

163 Baldwin exhibited odd behavior at times, missed the entire 1833 term, and was considered by some to be mentally deranged. See Robertson, supra note 99, at 52-53; G. EDWARD WHITE, THE MARSHALl COURT AND CULTURAL CHANGE, 1815-35, at 301 (1988) (noting Baldwin's “incoherence as a jurist.”).

164 See Mitchel, 34 U.S. at 746.

165 See Wilkins, supra note 16, at 159-60 (asserting that Mitchel "fundamentally contradicts the doctrines enunciated in M'Intosh" and establishes that "tribes are the possessors of a sacrosanct title that is 'as sacred as the fee-simple.”); Frank Shockey, “Invidious” American Indian Tribal Sovereignty: Morton v. Mancari Contra Adarand Constructors, Inc. v. Pena, Rice v. Cayetano, and Other Recent Cases, 25 AM. INDIAN L. REV. 275, 279 (2001) (asserting that the "as sacred as fee simple” definition in Mitchel conflicts with the characterization of aboriginal title in Fletcher $v$. Peck and Johnson $v$. McIntosh).

166 Cherokee Nation v. Georgia, 30 U.S. 1, 48 (1831) (emphasis added).

167 Johnson v. McIntosh, 21 U.S. 543, 592 (1823). 
fee simple title when it held that Indian title is not "property" for purposes of the Just Compensation Clause of the Fifth Amendment. ${ }^{168}$

The second passage in Mitchel $v$. United States that has caused confusion is Baldwin's statement that, "[t]he Indian right to the lands as property was not merely of possession, that of alienation was concomitant ...."169 This statement is the basis for Wilkins' assertion that a "critical review of Mitchel" reveals that "tribes may alienate their aboriginal territory to whomever they wish . ..." "170 Baldwin, however, was not stating that Indians can sell their lands to whomever they choose but rather that Indians may dispose of the right of occupancy if they have government approval to do so. The sentence in its entirety reads as follows:

The Indian right to the lands as property, was not merely of possession, that of alienation was concomitant; both were equally secured, protected, and guarantied by Great Britain and Spain, subject only to ratification and confirmation by the license, charter, or deed from the governor representing the king. ${ }^{171}$

John Marshall, in Johnson v. McIntosh, acknowledged that the Indian right of occupancy could be transferred to private individuals if done so with government sanction:

[T]he usual mode adopted by the Indians for granting lands to individuals, has been to reserve them in a treaty, or to grant them under the sanction of the commissioners with whom the treaty was negotiated. The practice, in such case, to grant to the crown, for the use of the individual, is some evidence of a general understanding, that the validity even of such a grant depended on its receiving the royal sanction. ${ }^{172}$

Although this statement does not precisely fit the facts of the Forbes

168348 U.S. 272, 279 (1955) ("Indian occupation of land without government recognition of ownership creates no rights against taking or extinction by the United States protected by the Fifth Amendment or any other principle of law.”); see also United States v. Cook, 86 U.S. 591, 593 (1874) (" $[T]$ he right of the Indians to their occupancy is as sacred as that of the United States to the fee, but it is only a right of occupancy.”); Watson, Discovery Doctrine, supra note 152, at 1021-24.

169 Mitchel v. United States, 34 U.S. 711, 758 (1835).

170 Wilkins, supra note 16, at 160; see also id. at 181 (“[T]he aborigines' right to dispose of the same to whomever they chose, [is] a right recognized in Mitchel but denied in M'Intosh ....”); WILKINS \& LOMAWAIMA, supra note 159, at 61 ("In a statement directly at odds with the McIntosh holding that Indians lack the power to convey their lands, the Mitchel court held that 'the Indian right to the lands as property was not merely of possession, that of alienation was concomitant; both were equally secured, protected, and guarantied by Great Britain and Spain.'”).

171 Mitchel, 34 U.S. at 758-59 (emphasis added).

172 Johnson, 21 U.S. at 598 (emphasis added); see also id. at 604 (rejecting "the general proposition, that a title acquired from the Indians would be valid... without the confirmation of the crown”). 
Purchase (which was licensed and approved by Spanish authorities, but not made part of treaty negotiations), it is clear that Mitchel does not reject Johnson's central thesis that European "discovery" of America divested native Indians of the "power to dispose of the soil at their own will, to whomsoever they pleased." 173 Baldwin makes clear, at several points in his opinion, that Indians can transfer their right of occupancy to private individuals, but only with government approval:

Individuals could not purchase Indian lands without permission or license from the crown, colonial governors, or according to the rules prescribed by colonial laws; but such purchases were valid with such license, or in conformity with the local laws; and by this union of the perpetual right of occupancy with the ultimate fee, which passed from the crown by the license, the title of the purchaser became complete... [their rights of occupancy were respected,] until they abandoned them, made a cession to the government, or an authorized sale to individuals. ${ }^{174}$

As previously discussed, the Spanish government both approved and confirmed the Forbes Purchase, and the Supreme Court in Mitchel acknowledged the validity of the actions taken by Governor Folch and other Spanish officials. Rather than embrace Marshall's views of the discovery doctrine set forth in Worcester, the Court in Mitchel endorsed and applied the Johnson discovery rule, by holding that discovery divested Indians of ownership, but did not divest them of rights of occupancy. ${ }^{175}$ Mitchel also follows Johnson by rejecting the view that Indian tribes possess unqualified disposition rights, holding instead that sales to private individuals require government sanction. ${ }^{176}$

\section{CONCLUSION}

The Forbes Purchase and Mitchel v. United States are important parts

173 Id. at 574.

174 Mitchel, 34 U.S. at 746 (emphasis added); see also id. at 750 ("Whether the grants were made to the king directly... or directly to the parties by a grant to them, must be a matter purely in the discretion of the king, or the officer whom he had authorised to accept or confirm the cessions by his license.") (emphasis added).

175 See Jill Norgren, Protection of What Rights They Have: Original Principles of Federal Indian Law, 64 N.D. L. REV. 73, 112 (1988) (“[T]he specific nature of the dispute in Mitchel permitted Justice Baldwin to clarify what had been conceded only in dictum in Johnson v. McIntosh, namely, that Indian title included the power to transfer as well as to occupy .... At the same time, however, the Court maintained its commitment to discovery theory and the dual, split nature of Indian land title.”).

176 See Nell Jessup Newton, At the Whim of the Sovereign: Aboriginal Title Reconsidered, 31 HASTINGS L.J. 1215, 1242 n.170 (1980) ("Mitchel made it clear that Indian tribes may alienate their occupancy right, though the sovereign's consent is necessary for the buyer to take a fee simple title.”). 
[Vol. 9:361

of Florida history. ${ }^{177}$ Johnson v. McIntosh, however, remains the leading Supreme Court case on native land rights. Although I respectfully disagree with the views of David Wilkins and Tsianina Lomawaima regarding the significance of Mitchel $v$. United States, I fully agree with their broader argument that the doctrine of discovery "is a clear legal fiction that needs to be explicitly stricken from the federal government's political and legal vocabulary."178 Whether viewed as divesting Indians of absolute disposition rights (Worcester) or as divesting Indians of ownership and absolute disposition rights (Johnson and Mitchel), the discovery doctrine is inconsistent with contemporary norms of indigenous rights and should be rejected.

177 Shortly after the Mitchel decision, the Apalachicola Land Company began promoting land sales and-for a brief period of time- the only Gulf of Mexico locations with larger populations and more commerce were New Orleans, Louisiana, and Mobile, Alabama. COKER \& WATSON, supra note 17, at 355; MARTIN, supra note 17, at 171; RogERS, supra note 43, at 6-27, 45-49. The boom period, however, lasted for about four years. MARTIN, supra note 17, at 174; Upchurch, supra note 37, at 139. In 1923, the Florida Supreme Court held that the Forbes Purchase did not include submerged lands under navigable and tide waters of a bay of the Gulf of Mexico. Apalachicola Land \& Dev. Co. v. McRae, 98 So. 505 (Fla. 1923). Today, most of the Forbes Purchase is either within the boundaries of the Apalachicola National Forest or is property owned by the St. Joe Paper Company. BRowN's Boundary Control AND Legal Principles 186 (Walter G. Robillard \& Donald A. Wilson eds., 6th ed. 2009).

178 WILKINS \& LOMAWAIMA, supra note 159, at 63; see also WATSON, supra note 2, at 355-58. 